\title{
A positive vision of sustainability
}

\author{
Steven A. Cohen ${ }^{1,2} \cdot$ Kelsie L. DeFrancia ${ }^{1} \cdot$ Hayley J. Martinez $^{1}$
}

(C) AESS 2016

\begin{abstract}
Growing population, increased urbanization, a growing global economy, and increased use of natural resources have created a demand for sustainability. Sustainability is an interdisciplinary field that requires collaboration from multiple perspectives. The planet's resources are all being used at a ferocious pace. Energy is at the center of this issue; dependence on fossil fuels is causing extensive damage to ecosystems and public health and is a major cause of global climate change. The goal of a renewable resourcebased economy is therefore important for the future, but rather than attacking the fossil fuel industry, it should be achieved through a positive vision of sustainability —one that includes the need to invest in basic and applied science of renewable energy in order to make renewables cheaper than fossil fuels. We will discuss the opportunities in sustainability-focused education and research that are needed for the transition to a renewable economy. We will also discuss the trend toward urbanization and the opportunities that exist in urban areas to close the cycle of production and consumption. Not only does most of the world's population live in cities, but cities are paving the path toward a sustainable future. All of these factors contribute to a positive and creative vision of sustainability that focuses on building something new and clean rather than defeating something old and dirty.
\end{abstract}

Steven A. Cohen

sc32@columbia.edu

1 The Earth Institute, Columbia University, New York, NY 10027, USA

22910 Broadway, New York, NY 10025, USA
Keywords Sustainability $\cdot$ Renewable energy $\cdot$ Education . Urbanization · Technology $\cdot$ Research and development

\section{Introduction: the integrated nature of sustainability}

The world faces an unprecedented global sustainability crisis. It is caused by climate change, the stress on the planet's ecosystems by developed economies, and the drive for economic growth in the developing world. While some choose to believe that the scientific analyses detailing the threats to our planet are inaccurate, the world that people experience today is different than even a generation ago. One simple fact: the planet had three billion people in the 1960s; today, it has over seven billion. The planet's population has more than doubled in half a century and it will likely grow to nine billion by 2050 . It defies logic to maintain that the planet's resources have been unaffected by this growth. There are significant challenges in meeting human needs while maintaining the planet's resources to a level sustainable to such growth.

Sustainable development is now an integral part of operations of governments and companies around the world and has become a central issue in economic and political dialog. The term itself has many definitions. The most commonly used definition is from the 1987 Brundtland Report, Our Common Future, which defined sustainable development as "development that meets the needs of the present without compromising the ability of future generations to meet their own needs" (World Commission on Environment and Development 1987). More contemporary definitions have added elements of social justice and equity to the concept of sustainable development. The connection and interaction between food, water, and energy is one example of a complicated, important, and interdisciplinary global sustainability challenge. The nexus of food, water, and energy is one of the most 
complex and critical issues that human society faces today, and the solutions to this problem must be carefully integrated to meet the needs of the future (Finley and Seiber 2014). This concept of 'nexus thinking' was first conceived by the World Economic Forum in 2011 to highlight the link between the use of resources to provide rights to food, water, and energy security (Biggs et al. 2015). There is now more demand for crossdisciplinary collaboration to develop solutions that align with this nexus thinking, in order to meet the increased demand for energy, food and water, and other resources that the billions of people on the planet will require (Machell et al. 2015). This type of nexus thinking is one basis for framing solutions to sustainability problems.

Related to sustainable development, the field of sustainability science is discussed in the literature as a fast-growing and uniquely varied emerging field and is one that crosses boundaries of many disciplines, including earth science, engineering, public policy, law, public health, and management. Sustainability issues cut across themes of climate change, energy, urbanization, global health, poverty, ecology, ecosystem health, water, and hazards, among others. Solutions to these issues therefore require an interdisciplinary understanding and multiple perspectives and must bring together theory, science, management, and policy (Bettencourt and Kaur 2011).

Sustainability challenges are multifaceted and long-lasting and threaten the economy, society, and the environment (Wiek et al. 2012). They are too complicated for the individual problem-solving capacities of governments, businesses, and civil societies, and so the solutions for sustainability must be built on diverse, collaborative partnerships (Wiek et al. 2015). The concepts of sustainable development transcend the traditional boundaries of scientific fields (Bettencourt and Kaur 2011).

\section{The path forward: a positive vision of sustainability}

Our planet is largely trapped in an economic system based on the one-time use of fossil fuels and other material resources, which is harming the environment and public health and is causing global climate change. However, scaring people with doomsday predictions - the media uses words like "dire," "alarming," and "dangerous" - is a losing approach to building an understanding of the facts of earth science. The way forward is to view sustainability in a positive light, by focusing on new technology and other innovations, education, and trends in urbanization that link sustainability and economic development, which will help us understand how we will live and thrive in such a world. Sustainability can offer a framework through which we can imagine a future and engage in the work necessary to get there (Greenberg 2013).

We are seeing a phenomenon in cities throughout the world and in organizations large and small; sustainability factors are being integrated into routine decision making. Organizational managers are increasingly focused on the physical dimensions of sustainability: their organization's use of water, energy, and other materials, as well as the waste and environmental impact of their production processes. The transition to a sustainable, renewable economy will only succeed if it is integrated into efforts to achieve other economic, social, and political goals. If sustainability is seen as a threat to a way of life that people value or if it threatens the power of the entire economic elite, then the transition to a renewable economy will be very difficult to achieve. A sustainable economy can be compatible with economic growth, but only if we do a much better job of understanding and managing the environmental impacts of economic production and consumption. Like globalization, it will eventually become an unremarkable part of modern life. Just as cable television replaced broadcast television, and the cell phone replaced the landline, electric cars will replace internal combustion engines when the technology becomes cheaper and makes peoples' lives easier. This will also be the case for the replacement of fossil fuels with clean, renewable energy; the way to build support for reducing the use of old and outdated technology is to create a vision of a more attractive, lower-priced, and convenient new technology.

A positive vision of sustainability ultimately includes: (1) the technological development for renewable energy fueled by research and scientific understanding; (2) environmental education at all levels that uses an interdisciplinary framework; and (3) a network of cities, where most of the world lives, that uses sustainability principles to govern and function. The government at all levels has a crucial role to play in this transition to a sustainable and urban economy, especially in encouraging and investing in the science and education that forms the foundation of our understanding.

\section{The role of science investment}

Energy is at the center of the sustainability challenge, as it is an indispensable ingredient of modern economic life. However, our long-term dependence on fossil fuels means a future of increased energy costs and greater environmental damage. While it seems convenient to attack the fossil fuel industry, it serves no real purpose since all of us are addicted to fossil fuels. Although fossil fuel interests have attempted to undermine the communication of climate science, the facts have triumphed and its time to focus on solutions. A more positive approach involves the American government and other national governments investing in the basic and applied science of renewable energy, energy storage, smart energy systems, and related technologies. To address the problem of climate change, we need to gradually replace fossil fuels with other forms of energy that are environmentally sustainable, such as wind and solar (Finley and Seiber 2014; Wong and 
Pecora 2015). Current renewable technologies are good but need to be better; we need breakthroughs in solar cells and other energy storage technology for it to be less expensive and more convenient. The batteries in electric cars need a range of 1000 miles rather than a few hundred. Home energy storage systems and solar cells must become smaller and less expensive. The technology must be so attractive that its adoption is virtually effortless. Embracing a positive vision of sustainability and making the transition to renewable energy is practical, feasible, and necessary.

Investment in basic and applied science is crucial to developing new energy technologies. According to statistics published by the National Science Foundation, overall US funding for research and development (R\&D) increased from $\$ 406.952$ billion in 2009 to $\$ 456.095$ billion in 2013 (Boroush 2015). Funding from the federal government decreased during this time but was offset by increases from the private sector, academia, and non-profits, though largely from the private sector. In 2013, business investment alone accounted for $71 \%$ of R\&D (Boroush 2015). Rather than focusing on basic and applied science, however, the business sector, driven by profits, tends to focus on the development aspect of $R \& D$ or innovations that are commercially viable. According to the Council on Foreign Relations, "Roughly two-thirds of all U.S. R\&D is focused on development, with the remainder split between applied and basic research. Basic or pure research does not have an immediate commercial objective, but is rather focused on developing new principles and theories that explain the natural world" (Markovich 2012). Without immediate gains, investment in basic research has shrunk significantly as a share of the economy, threatening American innovation (Porter 2015). One of the fundamental tasks that has historically been a function of the American government is to fund this basic science, which is needed to build the technological base for a sustainable economy.

While research in basic science can be less attractive to investors because returns on investment are too slow, there are a number of examples of federally funded research which have led to significant impacts and innovations (MIT Committee to Evaluate the Innovation Deficit 2015). Perhaps the best example is the personal computer, which has shrunk significantly in size since the 1970s and has dramatically increased in computing power. An appliance used by billions of people worldwide began as an investment by the US federal government, in order to develop better missile guidance systems for the US Department of Defense and smaller onboard computers for NASA's space program. In a similar vein, the precursor of today's Internet began as a way for the defense department computers to share data, started through the Advanced Research Projects Agency (ARPA) (Beranek 2000). The USA's status as the world's largest oil producer has its beginnings in federally funded research over four decades ago, which "led to directional drilling technology, diamond drill bits tough enough to cut shale, and the first major hydraulic fracturing experiments" (MIT Committee to Evaluate the Innovation Deficit 2015).

This basic science and technology was funded by the US government and took place in national and university laboratories. When the technologies matured, some were released for commercial use. In order to make the transition to a renewable resource-based economy, the federal government must provide funding for the technologies necessary to do so. Work on agriculture, water treatment, waste management, more efficient transportation systems, and a more sustainable built environment is also needed. The federal government must fund the basic research and enough of the applied research to demonstrate possible profitability.

Some efforts are underway. In September 2015, President Obama proposed a small increase in R\&D investment of $\$ 146.4$ billion or a $6.5 \%$ increase from the previous year (White House 2015). Currently, three new bills related to R\&D are currently awaiting Senate approval. Most significantly, the America COMPETES Reauthorization Act would prioritize federal investment in "basic research, fundamental scientific discovery, and development" for technological innovation (Congress.gov 2015). The White House stated that their priorities for investment in R\&D for fiscal year 2017 will focus on "global climate change; clean energy; earth observations; advanced manufacturing and industries of the future; innovations in life sciences, biology, and neuroscience; national and homeland security; information technology and high-performance computing; ocean and arctic issues; and R\&D for informed policy-making and management" (Donovan and Holdren 2015). While these funding efforts are important, the government needs to make significant additional investments and commitments to basic and applied research in order to facilitate the sustainability transition.

In addition to more advanced commercial technology to transition to a renewable resource-based economy, we also need more advanced science and sophisticated technology to study and understand the impact of human actions on vital natural systems. The air, water, and soil we require to stay alive cannot be degraded beyond repair if we are to sustain life. Earth systems science and observation is critical if we are to understand the conditions on our home planet and the dangers and opportunities presented by human-ecosystem interaction. We need to know more in order to understand what we can do to use the planet productively and what practices need to be avoided.

Many of the fundamental facts about our planet are still being explored and studied. It is critical to understand that the science of earth observation and environmental engineering has made it possible for us to grow our economy while reducing its toxicity to humans. People are living longer and healthier lives because of the marvels of modern medicine and the accomplishments of nearly half a century of environmental 
science, engineering, and policy. With further investment in these basic sciences, we can make the same progress in advancements toward sustainability and renewable energy.

\section{The role of education}

The transition to a sustainable economy requires that we transform our production and consumption processes to reduce their impact on natural planetary systems. This means that young people must learn about those systems, how they function, how we make use of them, how we endanger them, and how we might protect them. Forty years ago, environmental policy was a small, fringe issue. Today, environmental policy and sustainability are at the center of a global discussion. The challenge of global sustainability is now part of the permanent agenda of concerns that young people have internalized.

Increasingly, higher education institutions are beginning to reorient their education, research, and even operations toward sustainability initiatives (Wals 2014). Academic institutions are using many different formats to incorporate sustainability into student education, including research centers or institutions and integrating sustainability into the overall curriculum or through undergraduate and graduate degrees and certificate programs. Central College in Iowa, for example, requires that all students take a class in sustainability (2015), while Green Mountain College in Vermont requires each student completes a core sequence of social and ecological sustainability courses regardless of major (2015).

The City University of New York has launched a number of new sustainability programs, including a master's in sustainability in the urban environment, sustainable business, and sustainability science and education. The New School in New York City offers a master's in environmental policy and sustainability management, and Bard College, in Dutchess County, New York, began the northeastern region's first Master of Business Administration in Sustainability program. The Bren School of Environmental Science \& Management at the University of California, Santa Barbara, was established in the 1990s and now holds affiliations with six university research institutes and eight interdepartmental programs, supporting cross-disciplinary and comprehensive sustainability learning (The Regents of the University of California 2010). The Atkinson School of Management at Willamette University has a sustainability concentration, and Arizona State University has a thriving set of programs in its School of Sustainability. One of the nation's newest sustainability masters programs is at Wake Forest University in North Carolina, showing that sustainability in US higher education spans the nation.

At Columbia University in the city of New York, a number of master's programs have been developed to train sustainability professionals, such as the Master of Public Administration in Environmental Science and Policy and the Executive MPA Concentration in Sustainability Policy and Management at the School of International and Public Affairs, and the Master of Science in Sustainability Management at the School of Professional Studies (The Earth Institute 2015). Taken together, these programs enroll more than 300 students each year. In addition, schools at Columbia have also developed master's programs in climate and society and development practice, along with undergraduate and doctoral programs in sustainable development. None of these programs at Columbia existed before 2002. All provide rigorous, hands-on education in sustainability science, policy, and management, and all are evolving rapidly. As the world gets more crowded and complex, universities and faculty are in the process of evolving to meet the needs of that changing world.

Sustainability is now central to young people's understanding of the world, so students are getting more and more exposure to sustainability education at a younger age. Teaching young people to value the planet and the resources it provides is the way to ensure that our potential to solve the sustainability problem is achieved, but there are difficulties in incorporating sustainability into current educational structures. According to Don Krug, K-12 education systems often "do not have the necessary educational structure or curriculum organization in place to teach using a multidisciplinary, interdisciplinary, or integrated approach to pedagogy" (2012). The modern university is similar in that it is organized around discrete disciplinary fields, like biology and economics, or professional skills, such as engineering and law. This not only makes teaching new interdisciplinary subjects difficult but also presents challenges for the cutting edge interdisciplinary research that takes place at universities. While public policy schools have brought together many fields to attempt to solve policy problems and business schools have done the same in attempting to train business leaders, most lack the grounding in sciences and engineering needed to address the issues specific to global sustainability. We must bring together the fields of ecology, engineering, environmental science, chemistry, physics, law, medicine, public health, economics, political science, public policy, ethics, and management in order to help address the problems of climate change, renewable energy, ecosystem maintenance, water quality, and other sustainability issues. What is needed is a new form of academic organization that is university-wide, with the mission of institutionalizing interaction among all of these fields to address the problems of global sustainability.

Columbia University's Earth Institute is one example of this: a new form of academic institution that integrates the knowledge base of the twenty-first century university. Its mission is to develop programs of research, education, outreach, and practical application of knowledge to address the critical issue of global sustainability. The Earth Institute works to expand an understanding of the earth as one integrated 
system - studying the Earth and its environment, human society, and the interaction between the two - and training a new generation of interdisciplinary practitioners equipped with the tools to address this challenge. The institute includes over two dozen research centers or programs and has partnered with the university's schools to create, and in many cases, manage Columbia's sustainability educational programs mentioned previously.

The transition to a renewable economy requires education at every level. We need students in elementary schools, high schools, and colleges to develop a deeper understanding of the global sustainability crisis, but we also need aspiring professionals and current professionals to develop the expertise needed to begin the transformation in real time, today. Outside of the classroom, sustainability professionals must learn how to work with experts from many fields and are often the translators of environmental science to lawyers and finance experts. In organizations all over America and all over the world, young people are pushing to develop and implement sustainable practices and organizations. Many older professionals are returning to school to learn about sustainability, and many aspiring professionals are focusing their undergraduate and graduate education on sustainability science, engineering, policy, management, architecture, design, communication, and art.

The challenges humanity faces can be addressed but require a deep understanding of the trade-offs caused by our modern lifestyle. Today, learning is even more essential if we are to understand and come to grips with the crisis of global sustainability. The sustainability curriculum at all levels should stress interdisciplinary exchange and learning, team work, and problem-solving methodologies. Curricula must teach scientific, economic, social, cultural, and political facts and concepts to help students understand sustainability problems. The job of sustainability educators is to provide students with the analytic tools and conceptual framework to challenge easy answers. The problems in creating a sustainable economy are difficult, and many require tough trade-offs; there are no easy answers. Students must be able to perform the sophisticated analyses required to undertake critical thinking. This means that massive resources must be devoted to a range of scientific, policy, and management education programs.

\section{Sustainability and urbanization}

Urbanism is an ideal case study for looking at how to close the cycle of production and consumption that is the sustainability challenge. The world has become an increasingly urban place. There are currently 3.9 billion people living in urban areasmore than the number in non-urban areas, which has been true since 2007 (United Nations 2014). By 2030, the world will have 41 mega-cities with more than 10 million inhabitants each, and by $2050,66 \%$ of the world's population will be urban, which could be about 6.3 billion people (United Nations 2014). Thus, cities are important to a discussion about sustainability, not only for the 3.9 billion people living in cities now but also for the billions more that will be living in them over the next few decades. A renewable economy will mainly be an urban economy.

The size of an urban center or a city can vary; it can range from a few thousand to millions of people. Urbanization can be defined as the increasing concentration of people into an area's core (Champion 2001). Urbanization is highly connected to issues of economic and social development and environmental protection. Cities can be efficient, exciting, safe, and environmentally sound or they can be crowded, unplanned, dangerous, and wasteful. Government at all levels has a role to play in managing how well cities function. In most cases of urban revitalization, the government has played a key role in facilitating the process (Champion 2001). Government must build the energy, transportation, land use, water supply, sewage treatment, and waste management systems needed to allow the world's population to live in sustainable, densely settled cities.

More people are living in cities because they have become more attractive places to live - partly due to declining crime rates, but also due to rising incomes and education levels which increase the demand for urban amenities. Some studies have shown that large metropolitan areas are beneficial because they are centers of finance, corporate headquarters, advanced services, information, and technology (Champion 2001). Others say that more attractive architecture and public infrastructure influence the decision to move to cities (Dittrich-Wesbuer et al. 2008). Another study points to the effects of labor market conditions as a driving force for decisions to move somewhere; cities that have high wages, low unemployment, and high job creation attract labor (Buch et al. 2013). The quality of life that a city offers also matters, reflected in the presence of recreation areas, climatic conditions, and accessibility. Cities that have experienced resurgence are usually competitive, attract new and growing activities, and are therefore more interesting places to live; they develop a distinct and comparative advantage (Cheshire 2006; Storper and Manville 2006).

Another reason that some young people are moving away from suburbs and back to cities may in part be a rejection of a certain lifestyle. Based on the 1970-2000 US Census, young (ages 20 to 35), highly educated households tend to move toward places with higher-quality business environments, which is true regardless of marital status (Chen and Rosenthal 2008). Contrast that with retired-age people, who are attracted to improved consumer amenities and low cost of living (Chen and Rosenthal 2008). Young people are looking to consume in a different way and often in a more sustainable way. The cars, lawns, and costs of cooling and heating large suburban homes are in part replaced by biking, walking, mass transit, and smaller apartments where heating and cooling costs tend to be lower. 
These emerging consumption patterns reflect young people's concern over environmental sustainability. The growing number of people biking to work and shopping at local green markets is an indicator of this change. The number of cities, nonprofits, and corporations engaged in sustainability initiatives is another indicator of this change. More and more people born since the mid-1980s have internalized aspects of an environmental ethos. According to a University of Texas at Austin energy poll, there is growing support for environmental protection among millennials (2015). While Gallup continues to poll on what is a false trade-off between economic growth and environmental protection, their data nevertheless reports growing environmental awareness, especially among young people. Their recent polls report that younger age groups (Americans aged 18 to 29) are more likely to say that the environment should be given priority over economic growth, while those above age 65 are more likely to prioritize economic growth (Swift 2014). People and institutions are thinking about their use of natural resources and energy and the impact of their consumption on the planet. That trend is most pronounced among young people, and this type of social change will only gain momentum.

Not only are more people living in cities, but cities are also playing an increasingly important role in the sustainability of the planet (Bettencourt et al. 2010; Van den Berg et al. 2007). City governments have emerged as laboratories for sustainability and as leaders in designing and implementing sustainability action plans. Many local leaders have come to understand that sustainability drives economic growth (Svara et al. 2013). Green initiatives attract business, tourists, and new residents. People can see and experience local level sustainability initiatives because they have an immediacy not typically seen at other levels of government. Beautiful parks, exciting public spaces, good transportation, clean air, and clean water are all efforts to compete as a global city. Cities are turning to sustainable solutions that will attract new residents, stimulate economic growth, and encourage lifestyles based on renewable resources (Cohen et al. 2015).

As the provider of many important local services and operator of facilities, cities have a unique ability to take specific measurable action to reduce the use of fossil fuels and develop more ecologically oriented systems. Cities have direct control over critical systems like water and wastewater, waste and recycling, and building and zoning codes. Sustainability planning in cities needs to incorporate policies that influence all buildings and infrastructure (Cheshire 2006). City agencies should make their operations more energy and water efficient, and they should work to minimize the environmental impacts of the services they deliver. Many times, these initiatives also have health and economic benefits for the community and improve quality of life. For example, planning residential and mixed-use buildings around public transport, bike networks, and pedestrian facilities can reduce sprawl and carbon dependency (Institute for Transportation \& Development Policy 2010). Cities have the opportunity to redevelop existing areas through repurposing of vacant lots and urban infill-actions that return value to previously underutilized areas. Additionally, redeveloping brownfields (abandoned, contaminated industrial or commercial property) has proven to reduce crime, increase surrounding property values, create jobs, and encourage private investment (Zborel 2011). Investment in green space and urban forestry can reduce the urban heat island effect, reduce heating and cooling needs and costs, increase air and water quality, and provide a safe, welcoming environment for residents and visitors to enjoy (Zborel 2011).

A sustainable city is both livable and productive, and initiatives like these can result in both. City governments have been among the first to recognize that environmental quality and economic development go hand-in-hand. Sustainability policies are not distinct from the principles of good governance; they are increasingly central elements of those principles.

\section{Conclusion}

Sustainability is based on the premise that we are not compromising the needs of the future to address the needs of the present. But this is not just about the physical resources of water and food - it is about ensuring that the technology of the future provides a way to meet those needs, and that future generations have the knowledge base needed to solve the problems that we cannot predict. A positive and creative vision for sustainability focuses on building something new and clean rather than defeating something old and dirty. Sustainability should focus on positive possibilities rather than simply preventing damage and despair. The goal is not just to keep bad things from happening but to build technological, management, and social systems that help ensure that good things happen. We need a clean environment to enhance the quality of our lives, and this is a fact that will not change. Many parts of the USA are starting to see cultural and economic life moving in a direction that is less destructive of the planet by adopting the principles of sustainability.

The way forward is to view sustainability in a positive light, by focusing on the new technology and other innovations, education, and progressive initiatives in urbanization, to help us understand how we will live and thrive in such a world. We need to develop and deploy the technology to create a renewable resource-based economy and fund the basic earth science needed to better observe and analyze the earth's conditions. We must also devote resources to earth observation and a range of scientific, policy, and management education programs in order to ensure that the next generation has the understanding and tools needed to solve the world's global 
sustainability problems. Finally, we need to continue to create more sustainable built environments; by turning to sustainable solutions, cities can attract new residents, stimulate economic growth, encourage lifestyles based on renewable resources, and ultimately advance our progress toward global sustainability. It is a lifestyle focused on intellectual engagement and growth; physical fitness, health, and wellness; justice, fairness, and concern for others; and social engagement, interaction, friendship, and joy. All of these attributes can be achieved without destroying the planet. In fact, a concern for our own wellness, and that of our children and neighbors, can be extended to a concern for the sustainability of the planet itself.

\section{References}

Beranek L (2000) Roots of the internet: a person history. Mass Hist Rev 2: $55-75$

Bettencourt L, Kaur J (2011) Evolution and structure of sustainability science. Proc Natl Acad Sci U S A 108:19540-19545

Bettencourt L, Lobo J, Strumsky D, West G (2010) Urban scaling and its deviations: revealing the structure of wealth, innovation and crime across cities. PLoS ONE 5(11), e13541. doi:10.1371/journal.pone. 0013541

Biggs E, Bruce E, Boruff B, Duncan J, Horsley J, Pauli N, McNeil K, Neef A, Ogtrop F, Curnow J, Haworth B, Duce S, Imanari Y (2015) Sustainable development and the water-energy-food nexus: a perspective on livelihoods. Environ Sci \& Policy 54:389-397. doi:10. 1016/j.envsci.2015.08.002

Boroush M (2015) U.S. R\&D Increased in 2013, well ahead of the pace of gross domestic product. National Science Foundation. http://www. nsf.gov/statistics/2015/nsf15330/. Accessed 1 November 2015

Buch T, Hamann S, Niebuhr A, Rossen A (2013) What makes cities attractive? The determinants of urban labour migration in Germany. Urban Stud 51(9):1960-1978. doi:10.1177/ 0042098013499796

Central College (2015) Global sustainability. http://www.central.edu/ sustainability/in-the-classroom/. Accessed 27 October 2015

Champion T (2001) Urbanization, suburbanization, counterurbanization and reurbanization. In: Paddison R (ed) Handbook of urban studies. Sage, London, pp 143-162

Chen Y, Rosenthal S (2008) Local amenities and life-cycle migration: do people move for jobs or fun? J Urban Econ 64:519-537. doi:10. 1016/j.jue.2008.05.005

Cheshire P (2006) Resurgent cities, urban myths and policy hubris: what we need to know. Urb Stud 43:1231-1246. doi:10.1080/ 00420980600775600

Cohen S, Eimicke W, Miller A (2015) Sustainability policy: hastening the transition to a cleaner economy. Wiley, Hoboken, New Jersey

Congress.gov (2015) H.R. 1806-America COMPETES Reauthorization Act of 2015. https://www.congress.gov/bill/114thcongress/house-bill/1806/text. Accessed 28 October 2015

Dittrich-Wesbuer A, Föbker S, Osterhage F (2008) Demographic change and migration in city regions: results from two German case studies. ZammZ Angew Math Me 33:315-350. doi:10.1007/s12523-009-0019-0

Donovan S, Holdren JP (2015) Memorandum: multi-agency science and technology priorities for the FY 2017 budget. https://www. whitehouse.gov/sites/default/files/microsites/ostp/m-15-16.pdf. Accessed 28 October 2015

Finley J, Seiber J (2014) The nexus of food, energy, and water. J Agr Food Chem 62:6255-6262. doi:10.1021/jf501496r

Greenberg M (2013) What on earth is sustainable? Toward critical sustainability studies. Boom: A Journal of California 3(4):54-66

Green Mountain College (2015) Liberal arts with a purpose. http://www. greenmtn.edu/academics/environmental-liberal-arts-program/. Accessed 28 October 2015

Institute for Transportation \& Development Policy (2010) Sustainable development., ITDP, http://www.itdp.org/what-we-do/sustainableurban-development/. Accessed 28 October 2015

Krug D (2012) STEM education and sustainability in Canada and the United States. 2nd Annual STEM in Education Conference. http:// stem2012.bnu.edu.cn/data/long\%20paper/stem2012_87.pdf. Accessed 28 October 2015

Machell J, Prior K, Allan R, Andresen J (2015) The water energy food nexus - challenges and emerging solutions. Environ Sci: Water Res \& Technol 1:15-16. doi:10.1039/C4EW90001D

Markovich S (2012) Promoting innovation through R\&D., CFR Backgrounders, http://www.cfr.org/innovation/promotinginnovation-through-rd/p29403. Accessed 28 October 2015

MIT Committee to Evaluate the Innovation Deficit (2015) The future postponed: why declining investment in basic research threatens a US innovation deficit. Massachusetts Institute of Technology. http:// dc.mit.edu/sites/default/files/innovation_deficit/Future\% 20Postponed.pdf. Accessed 28 October 2015

Porter E (2015) American innovation lies on weak foundation., The New York Times, http://www.nytimes.com/2015/05/20/business/ economy/american-innovation-rests-on-weak-foundation.html?_r= 0 . Accessed 1 November 2015

Storper M, Manville M (2006) Behaviour, preferences and cities: urban theory and urban resurgence. Urban Stud 43:1247-1274. doi:10. 1080/00420980600775642

Svara J, Watt T, Jang H (2013) How are US cities doing sustainability? Who is getting on the sustainability train and why? Cityscape 15:9 44

Swift A (2014) Americans again pick environment over economic growth., GALLUP, http://www.gallup.com/poll/168017/americansagain-pick-environment-economic-growth.aspx. Accessed 27 October 2015

The Earth Institute (2015) A guide to educational programs in environmental and sustainable development at Columbia University. http:// issuu.com/earthinstitute/docs/education-guide $\mathrm{e}=4098028 /$ 2475352. Accessed 2 November 2015

The Regents of the University of California (2010) History., Bren School of Environmental Sciences \& Management, http://www.esm.ucsb. edu/about/about history.html. Accessed 1 November 2015

The University of Texas at Austin (2015) Energy poll. http://www. utenergypoll.com/wp-content/uploads/2014/04/October-2015-UTEnergy-Poll-Final2.pdf. Accessed 27 October 2015

United Nations (2014) Department of Economic and Social Affairs, Population Division. World Urbanization Prospects: The 2014 Revision, Highlights (ST/ESA/SER.A/352) http://esa.un.org/unpd/ wup/highlights/wup2014-highlights.pdf. Accessed 28 October 2015

Van den Berg A, Hartig T, Staats H (2007) Preference for nature in urbanized societies: stress, restoration, and the pursuit of sustainability. J of Soc Issues 63:79-96. doi:10.1111/j.1540-4560.2007.00497. $\mathrm{x}$

Wals A (2014) Sustainability in higher education in the context of the UN DESD: a review of learning and institutionalization processes. J Cleaner Prod 62:8-15. doi:10.1016/j.jclepro.2013.06.007

White House (2015) The budget. https://www.whitehouse.gov/sites/ default/files/omb/budget/fy2016/assets/ap_19_research.pdf. Accessed 27 October 2015 
Wiek A, Harlow J, Melnick R, Van der Leeuw S, Fukushi K, Takeuchi K, Farioli F, Yamba F, Blake A, Geiger C, Show R (2015) Sustainability science in action: a review of the state of the field through case studies on disaster recovery, bioenergy, and precautionary purchasing. Sustain Sci 10:17-31. doi:10.1007/s11625-0140261-9

Wiek A, Ness B, Schweizer-Reis P, Brand F, Farioli F (2012) From complex systems analysis to transformational change: a comparative appraisal of sustainability science projects. Sustain Sci 7:5-24. doi: 10.1007/s11625-011-0148-y
Wong K, Pecora C (2015) Recommendations for energy-water-food nexus problems. J Energy Resour Technol 137:032002-032002-5. doi: $10.1115 / 1.4028139$

World commission on environment and development (1987) Our common future. Oxford University Press, Oxford

Zborel T (2011) Sustainable connections: strategies to support local economies., National League of Cities, http://www.nlc.org/Documents/ Find \%20 City\%20Solutions/Research\%20Innovation/ Sustainability/sustainable-connections-strategies-to-support-localeconomies-mag-jun11.pdf. Accessed 28 October 2015 